BASIC REACTION KINETICS AND MECHANISMS 


\title{
BASIC REACTION KINETICS AND MECHANISMS
}

\author{
H. E. AVERY
}

Principal Lecturer in Chemistry Lanchester Polytechnic, Coventry 
(C) H. E. Avery 1974

All rights reserved. No part of this publication may be reproduced or transmitted, in any form or by any

means, without permission

First published 1974 by

THE MACMILLAN PRESS LTD

London and Basingstoke

Associated companies in New York Dublin

Melbourne Johannesburg and Madras

SBN 333126963 (hard cover)

333153812 (paper cover)

ISBN 978-0-333-15381-9 ISBN 978-1-349-15520-0 (eBook)

DOI 10.1007/978-1-349-15520-0

The paperback edition of this book is sold subject of the condition that it shall not, by way of trade or otherwise, be lent, resold, hired out, or otherwise circulated without the publisher's prior consent, in any form of binding or cover other than that in which it is published and without a similar condition including this condition being imposed on the subsequent purchaser. 


\section{CONTENTS}

Preface $\quad$ ix

1 Introduction 1

1.1 Kinetics and thermodynamics 1

1.2 Introduction to kinetics 1

1.3 Elucidation of reaction mechanisms 5

2 Elementary Rate Laws $\quad 8$

2.1 Rate equation 8

2.2 Determination of order of reaction and rate constant 11

2.3 First-order integrated rate equation 11

2.4 Second-order integrated rate equations 14

2.5 Third-order integrated rate equations 21

2.6 Opposing reactions 22

Problems 24

3 Experimental Methods for the Determination of Reaction Rates 27

3.1 Differential methods 28

3.2 Integration methods 31

3.3 Gas-phase reactions $\quad 41$

Problems 44

4 Dependence of Rate on Temperature 47

4.1 Arrhenius equation 47

4.2 Activation energy 48

4.3 Activated complex 53

Problems $\quad 57$

5 Theory of Reaction Rates 59

5.1 Collision theory $\quad 59$

5.2 Absolute rate theory 64 
5.3 Thermodynamic formulation of the rate equation

5.4 Entropy of activation

Problems

6 Theory of Unimolecular Reactions

6.1 Lindemann theory

6.2 Hinshelwood theory

6.3 RRK and Slater theory

78

Problems

7 Atomic and Free-Radical Processes $\quad 80$

7.1 Types of complex reaction $\quad 80$

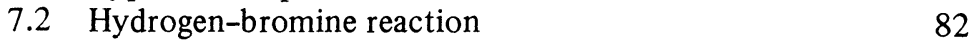

$\begin{array}{ll}7.3 \text { Rice-Herzfeld mechanisms } & 85\end{array}$

7.4 Addition polymerisation $\quad 89$

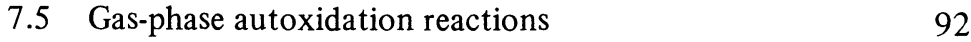

Problems 96

8 Reactions in Solution $\quad 99$

8.1 Comparison between reactions in the gas phase and in solution

$\begin{array}{ll}\text { 8.2 Transition state theory for liquid reactions } & 100\end{array}$

8.3 Reactions involving ions

8.4 Effect of pressure on reaction rates Problems

9 Catalysed Reactions

9.1 Homogeneous catalysis $\quad 114$

$\begin{array}{ll}9.2 \text { Acid-base catalysis } & 116\end{array}$

$\begin{array}{ll}9.3 \text { Heterogeneous catalysis } & 120\end{array}$

9.4 Enzyme catalysis

Problems

10 Photochemical Reactions 133

10.1 Laws of photochemistry 133

10.2 Excited-molecule processes 136

$\begin{array}{lll}10.3 & \text { Photolytic reactions } & 139\end{array}$

$\begin{array}{lll}10.4 & \text { Photosensitised reactions } & 141\end{array}$

10.5 Experimental methods $\quad 142$

Problems 145 
11 Fast Reactions 147

$\begin{array}{llr}11.1 & \text { Flow methods } & 149\end{array}$

$\begin{array}{lll}11.2 & \text { Flames } & 153\end{array}$

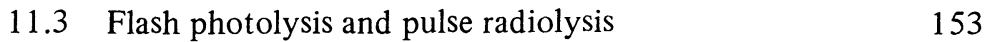

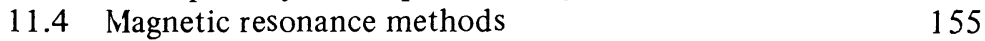

$\begin{array}{ll}11.5 & \text { Shock tubes } \\ 11.6 & 157\end{array}$

$\begin{array}{ll}11.6 & \text { Molecular beams } \\ 11.7 & 158\end{array}$

$\begin{array}{lll}11.7 & \text { Relaxation methods } & 159\end{array}$

$\begin{array}{ll}\text { Appendix } & 163\end{array}$

Table of physical constants and conversion factors 166

$\begin{array}{ll}\text { Answers to problems } & 167\end{array}$

$\begin{array}{ll}\text { Index } & 171\end{array}$ 


\section{PREFACE}

This book is based on a course of lectures given at Liverpool Polytechnic to both full-time and part-time chemistry students. In the experience of the author, many students find final-year kinetics difficult unless they have thoroughly grasped the basic principles of the subject in the first year of study. This book requires no previous knowledge of kinetics, but gives a more detailed account than that found in general physical chemistry textbooks. The purpose of this book is to give the reader a sound understanding of the fundamentals of the subject without dealing with the derivation of rate equations for typical complex reactions. The student is, however, introduced to a number of topics that will be dealt with more comprehensively in the final year of an Honours Chemistry course. With this in mind, the book should prove suitable for chemistry students in all years of Honours courses. It is particularly applicable to the first and second years of B.Sc. Honours Degrees, and for B.Sc. Ordinary Degree, Higher National Certificate, Higher National Diploma and Grad.R.I.C. Part 1 Chemistry courses. The book should also prove adequate for all the kinetics covered on B.Sc. combined science, biology, pharmacy and biochemistry courses.

The first four chapters cover the basic kinetic laws, the factors that control reaction rates and the classical methods used to measure reaction rates. These chapters cover the introduction to most kinetics courses. The basic theories of reaction rates are covered in chapters 5,6 and 8 , and a number of topics are introduced in a simple way. In chapter 7, the subject of atomic and free-radical reactions is treated comprehensively, since the author has found that the study of chain reactions has proved interesting and stimulating to many students; this area of kinetics has of course been a fruitful field of research for a number of years. The book concludes with a study of catalysed reactions, photochemical reactions and the development of new techniques for the study of fast reactions.

A number of worked examples are given throughout the book to illustrate the methods and relationships outlined. The reader is advised to test his knowledge of the subject on the kinetics problems that appear at the end of most chapters. For the diligent student, a list of key references, review articles and other textbooks for further reading are suggested at the end of each chapter.

Throughout the text, and for all the worked examples or test problems, 
the single system of SI units has been used. A selection of the units encountered most frequently in the book and a brief guide to the modern method of expression for physico-chemical quantities is given in an appendix.

The author wishes to express his appreciation to the students to whom he has taught kinetics at Liverpool Polytechnic and latterly at Lanchester Polytechnic, Coventry for their interest and keenness in the subject. I would also like to thank my wife for her continued help in preparing the manuscript and checking the text.

Some of the problems have been taken from past examination papers, and in this respect, I wish to thank the Universities of Brunel, Edinburgh, Hull, Lancaster, Liverpool, Manchester, Salford and Southampton for permission to publish.

H. E. Avery 